\title{
Gaps and Analogies in the Legal Definition of the Lease Facility in Russia
}

\author{
Viktor A. Mikryukov ${ }^{1}$ \\ ${ }^{1}$ Entrepreneurial and Corporate Law Department, Kutafin Moscow State Law University (MSAL), Moscow, \\ Russia \\ Correspondence: Viktor A. Miktryukov, Assistant Professor of the Entrepreneurial and Corporate Law \\ Department, Kutafin Moscow State Law University (MSAL), Candidate of Legal Sciences. Bld. 9, \\ Sadovaya-Kudrinskaya Str., Moscow 125993, Russia. E-mail: mikryukov.viktor@yandex.ru
}

Received: March 9, 2020

doi:10.5539/jpl.v13n2p82
Accepted: March 28, 2020

Online Published: May 25, 2020

URL: https://doi.org/10.5539/jpl.v13n2p82

\begin{abstract}
The study is relevant, as multi-variant rental relationships are wide-spread, requiring a seamless legal definition of the key elements of the lease design. The aim is to identify and, by analogy, comprehensively develop the legal regime of problematic and atypical leases, thus strengthening the doctrinal basis for filling legal gaps in the practice of applying civil law by analogy. Combined with special technical-legal and comparative-legal methodological tools, the article applied general logical methods of analysis, synthesis, induction, deduction, comparison and generalization. This research is peculiar in that the method of analogy acted simultaneously as a means, and as an object of study. Specific gaps in the legal definition of the list and properties of present and future things and their parts as admissible lease facilities were identified; a practical idea to improve the regulatory structure of the lease arrangement was formulated. The work helps to achieve greater contractual freedom and variability of economic activity, promotes the involvement of a greater number of material goods in the property turnover, at the same time helping to unlock the potential of the analogy method in the legal regulation of economic activity.
\end{abstract}

Keywords: gaps in lease law, analogy method, lease facility, civil legislation, analogy in law, lawmaking

\section{Introduction}

A lease contract is a common in practice legal structure of economic interaction, which is discussed in science. The right of temporary possession and (or) use of the leased facility based on the lease contract is endowed with the "resale value" (according to Article 617 of the Civil Code of the Russian Federation it "sticks" to the leased facility and remains valid in case of transfer of the encumbered ownership right to the leased facility from the lessor to another person), and therefore provides the leaseholder with a strong (not limited by the self-will of the owner) opportunity to satisfy his economic interest directly from the properties of the leased facility without getting it into ownership (and without baring the first cost). Lessor, by transferring the property to the leaseholder's temporary economic dominion, acquires a legally guaranteed opportunity to benefit (income in the form of rent) from the possession of the property, while retaining the title of its owner.

The demand of the lease contract in the economic turnover determined by the need to increase the economic efficiency of the legal construction of access of several persons to the value of one facility (and the current tendency to recognize the advantages of the "sharing economy" and its corresponding temporary use of the necessary facilities instead of buying things into individual ownership (Botsman and Rogers, 2010)), predetermines the necessity to identify and eliminate gaps in the diversity of rules forming this construction. At the same time, it is especially important to achieve full clarity in the legal definition of the lease facility, which constitutes core requirements to the essential condition of the lease facility contract recognized by the law.

\section{Materials and Method}

The research is practice-oriented, yet, being based on the analysis of legal proposals arising from existing laws, related court cases, legal theories and authoritative scientific materials on a set of specific legal issues (about gaps in the normative definition of the lease facility and problems of using it in contractual work), it is also the doctrinal one, i.e. it is more the "study of law" than the "study about law" (Kharel, 2018). 
Legal gaps that are not related to the qualified silence of a legislator inevitably lead to difficulties in enforcement and require the attention of the academic community. In this regard, a significant part of the research material was made up of formalized opinions of the highest courts (the Resolution of the Plenum of the Supreme Arbitration Court of the Russian Federation, July 23, 2009 № 64 "On certain issues of practice of disputes on the rights of owners of facilities on the common property of the building", the Resolution of the Plenum of the Supreme Arbitration Court of the Russian Federation, November 17, 2011 № 73 "On certain issues of practice of application of the rules of the Civil Code of the Russian Federation on the lease contract") and the judicial acts adopted in the resolution of specific disputes, which reveals the nature of the gaps.

Since any scientific research, including the civilized one, cannot be carried out without resorting to traditional logical techniques in the form of analysis and synthesis, induction and deduction, comparison and generalization, typology and analogy (Luneva, 2015), to the extent that these methods have been fully incorporated into the methodological basis of this work. The analogy method was of great importance, as it served not only as an element of the research methodology, but also as one of the central objects in the focus of consideration.

The tendency of development of civil law regulation towards integration and unification of methods of influence on similar economic relations in Russia and abroad led to inclusion of elements of comparativist analysis (Gordley and Mehren, 2006), i.e. reference to foreign experience of legal perception of some objects of lease and assessment of the role of the analogy in the mechanism of overcoming legal gaps in this sphere.

\section{Results}

The preliminary result was the need for detailed normative specification of the concept of the object of lease relations. Research of the practical problems arising due to the widening of the sphere of use of the lease contract construction for regulation of economic participation in benefits from other people's property, including at attempts to lease ambiguous and atypical lease facilities, has revealed four significant legal gaps:

1) Uncertainty of the legal approximate list of acceptable lease facilities, including uncertainty of the lease regime for construction-in-progress objects, retail and work places;

2) Ambiguity of normative specification of things leased as unused and individually determined, including incomplete certainty in nuances of providing animals for temporary use as a special group of "animated things";

3) Absence of direct regulation and contradictions in approaches to defining a part of the thing as a possible object of lease relations;

4) The gap in legal assessment of contractual relations of the future lease facility.

It has been proved that the judicial capacity to overcome these gaps by analogy of the law is efficient, while the relevant judicial practice (especially on the issue of lease of a part of the thing) is not stable enough. The efficiency and creative role of the analogy method in the legal regulation of economic activity, including in determining the object of the lease relations, has been scientifically and practically confirmed. At the same time, it was concluded that not all legal gaps, including some gaps in the area under consideration, should be overcome by analogy. Wrongly applied analogy may lead to violation of the regulatory structure used or undermine the economic viability of the regulated legal relations. Taking into account the results of the conducted theoretical analysis, it is proposed to improve the wording of Articles 606, 607 and 608 of the Civil Code of the Russian Federation concerning the concept of a lease contract and the range of acceptable lease facilities by means of specific legislative clarifications.

\section{Literature Review}

The legal concept of a lease contract formulated in Art. 606 of the Civil Code of the Russian Federation indicates that the object, which the lessor is committed to provide to the leaseholder for a fee into temporary possession and use or into temporary use, is property. Proceeding from the mentioned norm, such legally significant characteristic of the property, acting as the object of lease as its ability to satisfy the economic interest of the leaseholder by means of extracting useful qualities from this property by means of use which may be connected with temporary possession of the object, becomes clear. In this aspect, the judicial position that completely destroyed buildings cannot be the objects of lease is absolutely correct, because, given their inadequate technical condition, they lose their purpose, which indicates the impossibility to achieve the legal result that the conclusion of the lease contract is aimed at, namely, it becomes impossible to extract useful qualities from the object and use it in business activity (Ruling of the Arbitration Court of the Volga-Vyatka Region dated July 10, 2018, No. F01-2518/2018 with regard to case A43-25952/2017). The courts emphasize that the actual destruction of the objects of lease is the grounds for changing the lease contract and excluding such objects from the list of leased property (Ruling of the Arbitration Court of the Volga-Vyatka Region No. F01-1419/2019 dated April 19, 2019 
with regard to case No. A43-26742/2018). In the same vein, it is necessary to support the law enforcement approach, which reflects the civil and legal validity of the relationship of renting property under arrest or other security measures that restrict the owner in determining the legal fate of the facility, but do not prevent its exploitation and temporary compensatory use by third parties (Ruling of the Arbitration Court of the East Siberian Region, September 18, 2018, № F02-3250/2018 with regard to case A19-16449/2017).

At the same time, such legal assessment of the lease object is clearly insufficient for a proper understanding of the purpose and substance of the contractual relationship built by civil law subjects (Bulaevsky, 2018). The concept of "property" has a sufficiently broad content, depending on the specific civil law area of application, and can of a thing, things and property rights, a set of things, property rights and obligations (Shevtsiv, 2015), which, together with the ideas about the so-called "discorporate things" (Sazhenov, 2018; Fedotov, 2013) and due to the ubiquitous digitalization of public life of new "virtual property" objects (Pałka, 2016), including avatars and other "game" property (Lastowka, 2004), complicates the qualification of lease relations. Businessmen demonstrate a desire to rent out anything of any commercial value that may be of economic interest to the counterparty. Thus, there have been cases of conclusion of lease contracts for the route (permitted route of passenger buses) (Resolution of FAS Volgo-Vyatka District of July 30, 2013 on case № A79-6738/2012), The facts of the transfer for use under lease programs for electronic computers (Regulation of FAS Volga District on April 26, 2007 № A65-22625/06-SG3-15) and Internet sites (Regulation of the Moscow District Federal Commercial Court on the case A40-136634/12-140-976 dated September 6, 2013). The court practice has faced attempts to protect real property interests in case of "leasing" of virtual items from computer games (the decision of the magistrate court of the judicial district № 352 of Moscow Basmanny district from February 1, 2011, № 2-01/11, quoted in: Savelyev, 2014).

Therefore, the concept of an object of lease clearly requires normative specification. Unlike the Civil Code of the Russian Soviet Federative Socialist Republic, which does not specify the concept of "property" for the purposes of application of the norm of Chapter 27 "Property Hiring" (only the norm of Article 277 on the terms of the contract there were types of examples of possible objects like buildings, non-residential premises, equipment, household items, musical instruments, sports equipment, cars), the current Civil Code of the Russian Federation in Article 607 contains a following clarification: within the legal framework of the lease contract property is understood exclusively as substantial physical property.

This specification in the current market reality (with the desire of the participants of economic relations to maximize and diversify the benefits from any material goods belonging to them) seems quite natural, necessary and fundamentally important. Such specification makes it possible to exclude from the concept of lease rather similar contractual forms on granting for temporary use of computer programs and other intangible assets.

In particular, perceiving domain names as a kind of property objects (Lipton, 2009), business entities often try to use the design of the lease contract for their benefit by granting temporarily use of such objects to third parties (Decision of the Supreme Arbitration Court of the Russian Federation dated March 6, 2014, № SAC-2195/14 in the case № A40-136427/2012; Appellate Decision of the Lipetsk Regional Court of July 19, 2017 in the case № 33-2664/2017). Relevant authors note that a domain name shows its property value as an object of sale or lease and in this capacity actually participates in civil circulation (Galifanov, 2017). However, due to the non-material (discorporate) nature of a domain name, which excludes the possibility of its physical possession, the illegality of concluding domain lease contract is generally recognized (Rozhkova, 2018). The courts proceed from the assumption that a domain is not a thing or means of individualization, does not have owners, and therefore cannot be transferred into temporary possession and/or use under a lease contract, recognizing the respective contracts void (Ruling of the Ninth Arbitration Court of Appeal of September 26б 2014 No. 09AP-34280/2014-GC, 09AP-34281/2014-GC, 09AP-34282/2014-GC in case No. A40-169281/2013) and not related to leases (Ruling of the Intellectual Property Rights Court dated February 1, 2017 No. C01-1196/2016 in case No. A40-206553/2015).

Similarly, science and law enforcement assess common and mentioned in regulations (Art. 76 of the Air Code of Russian federation), the so-called "channel lease contracts" or "radio frequency spectrum lease contracts", which, without assuming the dynamics of material things (unless, of course, we are talking about equipment, infrastructure elements or linear cable structures (Ruling of the Federal Arbitration Court of the North Caucasus District on June 7, 2012 in the case number A63-5026/2011), in fact, are agreements on compensation for damages.

Since a share in the ownership of an object is not recognized as an object (although it is considered an independent object of civil law relations) (Zarubin, 2018), this rule allows a definite negative answer to the 
question whether the transfer of a share in the total share ownership without its apportionment is eligible (when trying to hire shares, the relevant lease contracts are recognized as not concluded due to the lack of proper conditions for the object) (Decision of the Supreme Arbitration Court of the Russian Federation of October 10, 2013 № SAC-14080/13 with regard to case № A33-16964/2012).

Apart from the fact that the range of lease objects is normatively limited to material (corporate) things, Article 607 of the Civil Code of the Russian Federation provides an open list of objects allowed for lease (land plots and other separate natural objects, enterprises and other property complexes, buildings, structures, equipment, vehicles and other things) and specifies that the leased objects should be unused, i.e. not losing their natural properties in the process of their use. This specification is not as clear and correct as the former. On the contrary, it leaves open the issues relevant to modern contractual and law enforcement practice and creates additional gaps.

Taking into account that legal certainty, which is a distinguishing feature of the rule of law and compatible with the ideals of a free market economy, plays a fundamental role in law due to its economic optimality for market participants (Portuese, Gough and Tanega, 2013), and bearing in mind the need to increase the quality of laws and the efficacy of their impact on the processes of formation and development of a new society in Russia (Mozolin, 2005), such a state of regulation, practical concretization and scientific assessment of lease objects is not acceptable. Since it is generally believed that the law should not be vague (an ambiguous law does not do well in managing people's behavior (Asgeirsson, 2015)), it is important that in the particular aspect under consideration to have the most correct and sound normative definition of acceptable lease objects.

\section{Discussion}

\subsection{Gaps in Legal and Regulatory Definition of Particular Types of Lease Objects}

The expediency of the regulatory emphasis in the general norm of Article 607 of the Civil Code of the Russian Federation on the legality of the lease of land plots and other separate natural objects, enterprises and other property complexes, buildings, structures, equipment and vehicles is seriously questioned. On the one hand, hardly anyone at all may have doubts about the ability of these types of things to act as the object of property rent, especially since the peculiarities of renting vehicles, buildings, structures and enterprises are disclosed in special paragraphs of Chapter 34 of the Civil Code of the Russian Federation. On the other hand, the open list does not include some objects which are in sufficient demand for transfer for temporary non-gratuitous possession and/or use, but which are ambiguously estimated in the structure of lease relations from the point of view of principle and practice.

Thus, although many lawyers recognize the results of construction in progress as quite capable of active involvement in the economic turnover as part of the lease facility (Kabakov, 2007; Melnikov, 2010), and we can conclude that the courts in general (mainly) share this position (Resolution of the West Siberian Region Federal Arbitration Court dated July 24, 2013 in regard to the case № A45-28338/2012; The Definition of SAC of the Russian Federation dated November 09, 2012 № SAC-14320/12 in regard to the case A40-106616/11-120-882), there are cases where the courts have rejected the legal possibility of leasing construction-in-progress facilities (the Regulation of Northwest Region Federal Arbitration Court dated July 17, 2006 in regard to the case A56-49787/04; the Regulation of Central Region Federal Arbitration Court dated 27.01.2009 in regard to the case № A14-2630-2008/85/17), which reflects the view expressed in science about the inability to fully use such objects, because the full use of the not yet created facility is impossible (Yargina, 2003). After the Federal Law dated December 30, 2004 No. 213-FZ "On Amendments to Part One of the Civil Code of the Russian Federation" was adopted, adding the words "objects of incomplete construction" into the norm defining real estate as an object of civil legal relations, the transferability of such objects stopped to be discussed (Valyavina, 2012). However, in this case it is a question of private doubts about the suitability of construction-in-progress objects to satisfy the economic interest within the framework of the lease contract framework. The lack of a clear answer to the question whether the lease of an unfinished construction project is allowed (Kondratenko, 2018), causes a decrease in the degree of legal certainty of property turnover regulation and weakening of commercial confidence of its participants, and causes legal conflicts.

It seems that it would be most productive to confirm (from the point of view of the lease contract framework) the principle legitimacy of the property lease of these complicated objects that would completely excluded the legal gap in the qualification of the relevant relations; and in the absence of legal and technical defects in the status of such objects themselves this would expand the basis for the boosted involvement of the results of unfinished economic activity in the economic turnover (this means, in particular, the absence of signs of unauthorized construction at a particular object (paragraph 11 of the Resolution of the Plenum of the Supreme Arbitration 
Court of the Russian Federation dated November 17, 2011 No. 73 "On Certain Issues of Practicing the Application of the Rules of the Civil Code of the Russian Federation on a Lease Contract"); the absence of a valid construction contract with regard to such an object (paragraph 21 of the Information letter of the Presidium of the Supreme Arbitration Court of the Russian Federation dated January 24, 2000 No. 51 "Overview of Dispute Resolution Practices under a Construction Contract"))

Further, difficulties arise with determining the regime of such "ambiguous" (as applied to leasing) objects as workplaces. In light of the emerging and ever more widespread economic phenomenon of "coworking" (UDA, 2013), most often perceived as a practice of short-term rent of workplaces for group and (or) individual work in a collective office, which (in comparison with the usual rent of office premises) allows one to minimize the cost of hiring premises and office supplies and contributes to the synergistic effect of several specialists working in the same workspace (Chegut and Langen, 2019), the certainty regarding the admissibility of using a lease as a legal form of temporary paid use of workplaces becomes morr and more relevant. In Russia, as the institution of self-employed citizens rapidly develops (together with choosing the method of legal registration of employment), the rent of workplaces has gained additional practical demand (Lyutov, 2019). Meanwhile, there is no certainty in this matter. In some cases, the courts consider the lease contracts of workplaces void as sham contracts, covering the transfer of non-residential premises for use (Decision of the Supreme Arbitration Court of the Russian Federation dated June 13, 2012 No. SAC-7136/12 in regard to the case No. A56-21650). There are situations when the courts, not finding agreed conditions on the specific location and (or) area and (or) the requirements for equipping the workplace as a temporary use facility, recognize lease contracts concerning such (insufficiently identified) workplaces as not concluded (Resolution of the East Siberian Region Federal Arbitration Court dated August 18, 2005 No. A58-5177 / 04-F02-3991 / 05-C2; Resolution of the Arbitration Court of the Moscow District dated December 13, 2017 No. F05-16991 / 2017 in case No. A40-166616 / 2016; Resolution of the Ural Region FAC dated June 09, 2008 No. F09-3660 / 08-C6 in case No. A07-14238 / 07). The most difficult thing in qualifying these relations is to identify and compare the signs of a lease with the constitutive features of service agreements. In a series of incidents, the courts qualified the contractual relationship for the provision of temporary use of the workspace as paid services (Resolution of the Far Eastern Region Arbitration Court dated August 05, 2019 No. F03-3100 / 2019 in regard to the case No. A51-13424 / 2018; Decision of the Supreme Court of the Russian Federation dated April 262018 No. 307-ES18-4272 in case No. A56-74640 / 2016).

Similar problems due to the uncertainty of the normative definition of the object of the lease contract arise in connection with the active use of this contractual design for providing and receiving trading places for temporary paid use. Some courts proceed from the fact that trading places do not have individualizing characteristics, are not isolated objects that could be transferred as a leased facilities (Resolution of the Federal Antimonopoly Service of the Volga Region dated March 3, 2010 in regard to the case No. A65-18040 / 2009), and tend to qualify such relations as the provision of paid services (Resolution of the Ural Region Federal Arbitration Court dated July 21, 2009 No. F09-5003 / 09-C5 in regard to the case No. A60-40089 / 2008-C4; FAS Resolution of the Central District Federal Arbitration Court dated January 26, 2010 No. F10-5949 / 09 in regard to the case No. A14-3407 / 2009/81/32). Others point to the subjection of this kind of relationship to the norms of the Civil Code of the Russian Federation on leasing (Resolution of the Presidium of the Supreme Arbitration Court of the Russian Federation dated November 19, 2013 No. 8668/13 in case No. A82-3890 / 2012; Resolution of the Arbitration Court of the North Caucasus District dated April 05, 2018 No. F08-396 / 2018 in case No. A63-16575 / 2016), which finds theoretical approval (Nikitin, 2014).

It is thought that if the participants in the relations in question actually intend to provide (receive) not the premises (building) as such (or part of it) for temporary use, but the ability to use the "spatial zone equipped with the necessary facilities in which the employee or the group work jointly performing production tasks" (Such a definition of a workplace can be found in Appendix No. 3 to the Procedure for quoting workplaces in organizations of the city of Moscow (approved by Resolution of the Moscow Government dated March 24, 1998 No. 229.) https://www.mos.ru/authority/documents/doc/19079220) or "place on the market (including a pavilion, kiosk, tent, tray), specially equipped and reserved by the market management company, used to carry out activities for the sale of goods (work, rendering of services)" (This concept of a trading place can be found in clause 8) of Art. 3 Federal Law of December 30, 2006 No. 271-FZ "On Retail Markets and on Amendments to the Labor Code of the Russian Federation"), there is no reason to refuse to use the design of the lease contract with its inherent rules, ensuring proper durability and stability of the legal relationship of counterparties (Article 610 of the Civil Code of the Russian Federation on the lease term; clause 3 of Article 614 of the Civil Code of the Russian Federation on the minimum terms for reviewing the amount of the rent; Article 617 of the Civil 
Code of the Russian Federation on maintaining the lease in force upon transfer of the right to leased property from the lessor to another person ), which is correctly reflected in some judicial acts (Resolution of the Arbitration Court of the Far Eastern Region dated January 19, 2015 No. F03-5830 / 2014 in regatd to the case No. A24-2385 / 2014). Therefore, the work (and trading) places, as well as the results of construction in progress, deserve to be named among the acceptable lease facilities in Art. 607 of the Civil Code of the Russian Federation.

Achieving the absolute lack of legal regulation of this issue will simultaneously solve a very significant business (though not important in theoretical terms) question of whether a written contract for a lease of a workplace (or trade) place is an appropriate proof of the location of a legal entity at its address reflected in the Unified State Register of Legal Entities. On the one hand, the absence of a direct legislative prohibition on using the address of a coworking center or other premises (or buildings) within which this organization rents a workplace as the official (registered) address of an organization, indicates the illegal nature of the actions of tax (registration) bodies that impede the creation and activities of legal entities with such an address and with such documentary evidence of the right to use it (Resolution of the West Siberian Okrug the Arbitration Court dated May 13, 2016 № F04-1311 / 2016 in regard to the case number A81-4028 / 2015). On the other hand, cases of negative public evaluation of lease contracts concerning workplaces for the purpose of conducting business through a legal entity per se (despite the fact that such an assessment sometimes finds judicial confirmation (Resolution of the Fifth Arbitration Court of Appeal of 11.07.2014 No. 05AP- 6627/2014 in the case No. A51-38970 / 2014)) shows the need for including workplaces into legal lease facilities.

The judicial practice accumulated to date shows that the courts adequately perceive one of the cornerstones for the civil law sphere as the principle of contractual freedom and, explicitly referring to it in judicial acts (Resolution of the Volga-Vyatka Region FAC dated July 9, 2014 in regard to the case No. A28-15310 (2013), correctly identify the vector of legal impact set by the legislator by means of special regulatory inclusion in the economic turnover of such objects similar to workplaces and trading places by their legal ambiguity as parking spaces (in paragraph 3 of clause 1 of Article 130 of the Civil Code of the Russian Federation, introduced by the Federal Law of July 3, 2016 No. 315-FZ as applied to the concept of a real estate property, it is specifically specified that parts of buildings or structures intended to accommodate vehicles belong to real estate (parking lots). Moreover, scientists recall a way to fill in legal gaps as an analogy to the law (Article 6 of the Civil Code of the Russian Federation), which, in the absence of special regulation, allows courts to effectively apply lease provisions to relations of paid use in case of any "atypical" objects, if this does not contradict the essence of the relevant relations (Kratenko, 2007).

However, bearing in mind the theoretical postulate that exact rules more consistently regulate simple phenomena (to which the issue in question can clearly be attributed) than principles (Braithwaite, 2002), and also considering that the mechanism for applying legislation by analogy, although it has the aim the achievement of absolute legal certainty in itself is fraught with discretion of the law enforcer, which is close to the manifestation of judicial law-making (Schauer and Spellman, 2017) and therefore carries the risk of abuse (Momotov, Uletova and Markova-Murashova, 2011), it seems possible and advisable to achieve in this aspect the maximum legal certainty precisely in the normative (and not causal enforcement) way.

\subsection{The Gap in the Legislative Recognition of the Legal Properties of Lease Facilities}

The normative specification of the things being leased out as non-consumable seems both ambiguous and absent.

This rule is interpreted in the following way: lease objects in all cases are non-consumable things (indestructible and unchangeable, apart from normal wear and tear) and individually defined (see: Commentary on the Civil Code of the Russian Federation, parts second (itemized) / edited by S.P. Grishaev, A.M. Erdelevsky // ATP Consultant Plus. 2007). Such an understanding raises doubts about the correctness of the affirmative answer to the question of whether it is possible to lease consumable things that are individual, but individualized for the purpose of lease, if the leaseholder does not use them in terms of destruction (for example, if transfer is made for temporary possession together with using five bags of apples to decorate and shoot apple juice advertising).

In this aspect, one should agree with the opinion that it is necessary to recognize that generic things, including consumed ones, can be the subject of lease relationships (Belov, 2018; see also: Commentary on the Civil Code of the Russian Federation. Part Two: practical and practical commentary. Ed. by A.P. Sergeyev. Moscow: Prospect, 2010. Access from ATP "Consultant Plus"). It seems quite understandable that, pointing to the non-consumable nature of the leased object, the legislator intended to clearly distinguish the lease from a commodity loan and only had in mind that the leased object should not be used (processed, destroyed) as a result of the leaseholder's use, and that the leaseholder is obliged at the end of the lease to return the same property. For 
example, if we are talking about renting several bags of apples for the purpose of performing advertising photography, then the leaseholder may well be obliged by cotract to return those same apples. In order to stop scientific discussions about the admissibility of classifying property as a leased facility and to exclude legal disputes based on the consistency of individual characteristics of leased property (Resolution of the Third Arbitration Court of Appeal of March 10, 2015 in case No. A33-22593 / 2013), it seems appropriate to clarify the regulatory concept of the object of lease.

An appropriate clarification of the required legal properties of the leased facility will also help to achieve full certainty in the nuances of the provision for temporary use of animals that are special objects of property relations that are introduced by the legislator into a special category of so-called "animated things" (Gorokhov, 2017). Thus, the special qualities of animals (the ability to grow, change in the process of life, die) may raise doubts about the admissibility of their rent, since there are difficulties in individualizing each animal (especially if, for example, we are talking about renting a herd, swarm or family (Resolution of the Federal Antimonopoly Service of the Ural Region dated April 21, 2010 No. F09-2663 / 10-SZ)) and in a certain sense, the leaseholder is simply not able to return the same(identical) animal to the lessor. For example, if the calves are leased, then in a few months the leased object will turn into property of a different kind and quality, namely adult animals (cows), which, according to some courts, will exclude the possibility of their return in kind (Resolution of the Ural Region FAC dated July 142004 No. F09-2113 / 04-GK).

It seems that, by pointing to the non-consumable nature and, as a result, the individually defined nature of the property as an object of lease, the legislator actually had in mind the inadmissibility of a conflict between the contractual structures of the lease and the commodity loan (inability to consume the leased objects under the lease, and mix them with other things of the same kind and quality and returning the same, but not the same property) and thus made a terminological error, which, for a number of excusable reasons, are common (Golubtsov, 2018). As a result, the legislator violated the required balance between regulatory flexibility and the narrow concept of legal certainty (Krajewski, 2013).

\subsection{The Gap in the Legal Definition of the Part of the Object as a Lease Facility}

Up until now, the wording of Art. 607 of the Civil Code of the Russian Federation does not provide an answer to the urgent and very frequent question of the applicability of the contractual construction of leases to relations associated with the use of individual parts of a thing, including structural elements of buildings, as well as parts of movable things.

For a long time in judicial activity, the legislator's silence regarding the legal regime for the lease of certain elements of an object was regarded as a case of "qualified silence of a negative type" (Langenbucher, 1998), equivalent to an implicit ban that cannot be overcome in law enforcement activities neither through interpretation nor through the analogy. So, in paragraph 1 of the Information letter dated January 11, 2002 No. 66 "Overview of the practice of resolving disputes related to lease," the Presidium of the Supreme Arbitration Court of the Russian Federation supported the position on the inadmissibility of qualifying as a lease contract concluded with the building owner, on the basis of which the owner's counterparty carries out a payment use of a separate structural element of the corresponding building (for example, facade or roof) for advertising purposes. Having recognized the opportunity to place advertisements on a roof or other parts of the building as legitimate (not contrary to law), the court emphasized that the structural element of the building is not an independent real estate object that could be transferred for use separately from the entire building, therefore, it cannot be a leased facility. In other words, the Presidium of the Supreme Arbitration Court of the Russian Federation saw in the rules of Art. 607 of the Civil Code of the Russian Federation, a ban on concluding a lease contract for a part of an object, although it recognized the contractual use of a part of the thing as permissible by means of some other (not specified in the law) contract. As a result, the relevant contracts began to be considered a classic example of unnamed agreements that do not include elements of other (named) agreements (Ksenofontov, 2018; Lyovushkin \&Fedchenko, 2014).

The significant actual spread of relations of limited paid use by third parties of certain elements of immovable buildings and structures that belong to the owner in the absence of a special mechanism for their regulation pushed judicial practice to use the lease institution as a well-developed and most appropriate substance of the relevant connections. Continuing to reject the qualification of disputed relations as a lease and insist on their unnamed contractual nature, the courts came to the need to apply lease rules to these types of unformalized contracts by analogy. The corresponding clarification was formulated in paragraph 7 of the Resolution of the Plenum of the Supreme Arbitration Court of the Russian Federation dated July 23, 2009 No. 64 "On some issues of the practice of resolving disputes on the rights of owners of premises to the common property of a building", 
where the Plenum not only pointed out the analogy of the law as a means of filling the legal gap, but it also extended the effect of most of the norms of the whole institution (lease) to whitespace relations, including the norm on the encumbrance of leaseholder's rights (encumbrance with the right to use a separate building element is set to the whole building). A number of authors regard such a turn in assessing the mechanism for determining the interrelations between the part of an object and permissible lease objects, as the fact that the higher court, resorting to a "wholesale" (and therefore "anomalous") analogy, disavowed the legal consequences of classifying disputed contractual relations as unnamed (Karapetov and Saveliev, 2012).

Despite the fact that in the theory of law and civil law science, the use of the analogy of the law is considered effective (Romanenko, 2016) and a traditional (Malyushin, 2015) legal instrument to bridge legal gaps, the existence of which in the field of civil law is recognized as immanent to the rulemaking process (Gordley and Mehren , 2006), and despite the fact that (contrary to the above judgment) the "wholesale" analogy (or the legal regime analogy) is by no means anomalous, the attempt of the Plenum of the Supreme Arbitration Court of the Russian Federation to seal the legal gap in question with the help of analogy (and not through the improvement of existing legislation or broad interpretation) actually led to the fact that the analogy was used as a tool for designing proprietary encumbrances. So, since the Plenum of the Supreme Arbitration Court of the Russian Federation, using analogy, has vested the rights of third parties using the structural elements (parts) of the building with the proprietary qualities of "sticking" to the object (according to Clause 1, Article 617 of the Civil Code of the Russian Federation, transfer of ownership of the leased facility to another person does not constitute a basis for amending or terminating the lease contract), since there was a clear unlawful intrusion into the principle of an exhaustive regulatory list of property rights "numerus clausus" (Merrill, 2000), directly enshrined in Art. 216 of the Civil Code of the Russian Federation. Moreover, the application of rental rules to relations of paid temporary use of a part of a building is not directly, but by analogy, watered down the solvency of the contractual form of lease, its ability to legally back the sustainable temporary compensated use of someone else's facility.

All this led to the adoption of the clarifying Decision of the Plenum of the Supreme Arbitration Court of the Russian Federation of November 17, 2011 No. 73 "On Certain Issues of Practicing the Application of the Rules of the Civil Code of the Russian Federation on a Lease Agreement". Its clause 9 states that the provision of Art. 607 of the Civil Code of the Russian Federation, which defines land and other separate natural objects, enterprises and other property complexes, buildings, structures, equipment, vehicles and other things that do not lose their natural properties during their use (non-consumable objects) as lease facilities subject to the norms of Art. 606 of the Civil Code of the Russian Federation on the possibility of transferring the leased object only for use by the leaseholder (without granting the right of ownership), does not limit the right of the parties to conclude such a lease contract, under which the leaseholder is not provided with the whole object, but only a separate part thereof.

It would seem that these changes in judicial approaches hinder the increase in the overall level of efficiency of regulation of economic activity, which requires sufficient certainty, stability and predictability. Given the fact that even after the last clarification at the highest court level, one can find acts of lower courts that implement the previous approaches (Resolution of the FAC of the Volga-Vyatka Region dated September 18, 2013 in regard to the case No. A17-7144 / 2012). It means the danger of incorrect use of the legal analogy, and thus it seems necessary to enshrine an indication of the possibility of renting the part of the leased facility in law.

\subsection{The Gap in the Legal Definition of the Admissibility of Lease Contract in Relation to the Future Facility}

It seems clear that the exercise of economic dominance over a thing (possession) and its beneficial use in terms of a lease is possible only in cases where it is a concrete thing that currently exists and is available to the leaseholder. At the same time, it is quite realistic to think about concluding a lease contract with respect to a thing that will be acquired or created by the lessor and after that it has been given for possession and (or) use to the leaseholder. However, the norm of Art. 607 of the Civil Code of the Russian Federation, defining the object of lease relations, does not specify such situations. Moreover, according to Art. 608 of the Civil Code of the Russian Federation, the right to lease property belongs to its owner, which means that, by literal interpretation, one can deduce a rule prohibiting a person from entering into an agreement to lease a thing that does not already exist or with respect to which this person does not have the right to make a lese contract (in reltion to future things).

This gap together with the rule of Art. 608 of the Civil Code of the Russian Federation led to the fact that some courts stated the invalidity of lease contracts concluded at the time when the lessor had no right to the leased object, and thus refused to charge for the actual lease period (Resolution of the Far Eastern Region FAC dated 
March 20, 2007 No. F03-A04 / 07-1 / 549 in regard to the case No. A04-1536 / 06-4 / 63). They accordingly came to the conclusion that obligations arise from unjust enrichment (Decree of the Presidium of the Supreme Arbitration Court of the Russian Federation of November 29, 2011 No. 9256/11 in case No. A73-10207 / 2010).

This practice, being doctrinally and economically "unjustified" (Karapetov and Bevzenko, 2014), underwent a radical change when the Plenum of the Supreme Arbitration Court of the Russian Federation in paragraph 10 of Resolution No. 13 dated January 25, 2013 "On Amendments to the Resolution of the Plenum of the Supreme Arbitration Court of the Russian Federation" dated November 17, 2011 No. 73 "On Certain Issues of Practicing the Application of the Rules of the Civil Code of the Russian Federation on a Lease Agreement" recommended lower courts to take into account that, based on the meaning of the norm, Art. 608 of the Civil Code of the Russian Federation, a lessor who has entered into a lease contract and has undertaken to transfer property to the leaseholder for possession or for use, must have the right to own it not at the date of conclusion of the contract, but at the time of transfer of the facility to the leaseholder, and therefore the lease contract concerning future thing is not invalid (unless, of course, we are talking about the nullity of the lease agreement for the future immovable concluded in relation to unauthorized construction). The SAC Plenum further clarified that the lease contract concluded on the side of the lessor by a person who, at the time of the transfer of the property to the leaseholder was the legal owner of the real estate, but did not ensure the state registration of his ownership of this property, also does not contradict the law.

These judgments of the Plenum of the Supreme Arbitration Court of the Russian Federation do not formally rely on the mechanism of the analogy, but are explicitly made taking into account the similar approach of the legislator to solving the issue of concluding a purchase and sale agreement for a future thing. Thus, in accordance with paragraph 2 of Art. 455 of the Civil Code of the Russian Federation, upon agreeing on the terms of the contract concerning sale of goods, the seller and the buyer have the right to provide goods, both available from the seller at the time of conclusion of the contract, and goods that will be created or acquired by the seller in the future. In order to implement the creative function of the legal analogy method, it seems necessary to capture similar provisions in Art. 607 of the Civil Code of the Russian Federation, which will make it possible to achieve full and firmsolid legal certainty regarding the admissibility of concluding lease agreements for future things.

As an additional confirmation of the correctness of such an improvement, it should be pointed out that it is necessary to ensure that the general lease provisions comply with its individual elements. So, since the norms of Art. 665 of the Civil Code of the Russian Federation on a financial lease agreement as a special type of lease agreement provide for the conclusion of an agreement with respect to a thing that the owner agrees to acquire in the future from the seller indicated by the leaseholder (i.e., they directly and unequivocally legalize the lease agreement for the future thing), insofar as the general standards should at least allow for the possibility.

\section{Conclusions}

The study showed that at present, the legal definition of a leased facility is a whitespace, as it does not provide an adequate level of contractual freedom and commercial confidence of participants in lease relations. Moreover, the analogy of the law as a tool to overcome legal gaps is not used consistently by the courts, and in some cases leads to destructive consequences. This indicates the need to improve the current legislation.

On the one hand, the legislative act is efficient when it is stable (Demiyeva, 2017), while the growth of legislative initiatives and a radical change in existing regulation deprives civil legislation of the necessary stability (Sinitsyn, 2017). On the other hand, even the Civil Code of the Russian Federation, being a kind of "economic constitution" of the state, requires regular updating in order to be adequate to changing public relations (Golubtsov, 2016). Therefore, it seems possible and appropriate to specify the concept of a lease object in the text of the Civil Code of the Russian Federation in a new way.

The text of paragraph 1 of Article 607 of the Civil Code of the Russian Federation should be stated as follows:

"Article 607. Objects of lease

Land plots and other separate natural objects, enterprises and other property complexes, buildings, structures, equipment, transport vehicles and other things, which do not forfeit their natural properties in the process of their use (non-consumed things) may be let on lease.

The parties have the right to conclude such an agreement that will have the leaseholder using not the whole object, but the part of it".

For the final legitimization of lease contracts concerning future objects the Article 608 is to be as reworded: 
“Article 608. Lessor

The right of leasing property shall belong to its owner. Lessors may also be represented by the persons who are authorized by law or by the owner to let property on lease.

A lease agreement concluded by a person who at the time of its conclusion did not have ownership of the leased object (lease agreement for a future object) is not invalid".

Given the expungement from the Art. 607 of the Civil Code of the Russian Federation, indications of the non-consumability of leased objects, text of the Art. 606 of the Civil Code of the Russian Federation should be supplemented by an indication that the leaseholder is obliged to return to the lessor not the identical, but the same thing, which would prevent the mixture of lease and a commodity loan. Accordingly, the wording of Art. 606 of the Civil Code may be reworded as follows"

"Article 606. Lease agreement

Under the lease agreement (contract for lease of property) the lessor shall undertake to furnish to the leaseholder (hirer) property for charge in temporary possession and use or in temporary us, while the latter is obliged to return the same object in the same state considering wear and tear or other contract stipulations".

\section{References}

Asgeirsson, H. (2015). On the Instrumental Value of Vagueness in the Law (October 1, 2014). Ethics, 125(2), 425-448. https://doi.org/10.1086/678480

Belov, V. (2018). Lease Agreement: Scientific and Educational Essay. Moscow.

Botsman, R., \& Rogers, R. (2010). What is Mine Is Yours: The Rise of Collaborative Consumption? Harper Business.

Braithwaite, J. (2002). Rules and Principles: A Theory of Legal Certainty. Australian Journal of Legal Philosophy, 27, 47-82. https://doi.org/10.2139/ssrn.329400

Bulayevsky, B. (2018). Essential terms of the contract: some problems of definition. Laws of Russia: experience, analysis, practice, 4, 103-106.

Chegut, A., \& Langen, M. (2019). The Financial Impacts of Coworking: Rental Prices and Market Dynamics in the Commercial Office Market. Econometric Modelling, 2019. https://doi.org/10.2139/ssrn.3481142

Commentary on the Civil Code of the Russian Federation, part two. (2007).

Commentary on the Civil Code of the Russian Federation, part two. (2010). Moscow.

Demiyeva, A. (2017). Legislation on entrepreneurial activity: current status and development prospects. Lawer, $12,4-9$.

Fedotov, D. (2013). On the issue of incorporating incorporeal property in the list of property rights. Lawer, 23, $39-42$.

Galifanov, R. (2017). Features of the legal relationship of domain names and trademarks. Industrial Property, 8 , $33-48$.

Golubtsov, V. G. (2016). The Principle of Good Faith as an Element of the Legal Mechanism for Stimulating the Debtor to Proper Execution of Obligations and Guaranteeing Creditors' Interests: Analysis of Judicial and Arbitration Practice. Perm University Herald. Juridical Sciences, 32, 175-184. https://doi.org/10.17072/1995-4190-2016-32-175-184

Golubtsov, V. G. (2018). Reform of the Law of Obligations: Theoretical and Practical Effect of The Changes Introduced. Perm University Herald. Juridical Sciences, 41, 396-419. https://doi.org/10.17072/1995-4190-2018-41-396-419

Gordley, J., \& Mehren, A. T. (2006). An Introduction of Comparative Study of Private Law: Readings, Cases and Materials. Cambridge; New York: Cambridge University Press.

Gorokhov, D. (2017). Modern lawmaking in the sphere of keeping, using and protecting animals. Journal of Russian Law, 4, 138-153. https://doi.org/10.12737/article_58e39ece96d568.74247445

Guzanov, K. (2017). Peculiarities of the use of contracts named and not named in the Civil Code of the Russian Federation in the field of communication services. Civil Right, 1, 37-41.

Kabakov, A. (2007). Leasing the construction-in-progress objects. Judicial Arbitration Practice of the Moscow Region, 4, 84-88. 
Karapetov, A., \& Bevzenko, R. (2014). Commentary on the rules of the Civil Code on certain types of contracts in the context of the Resolution of the Plenum of the Supreme Arbitration Court of the Russian Federation "On freedom of contract and its limits". Bulletin of Economic Justice of the Russian Federation, 9, 6-106.

Karapetov, A., \& Savelyev, A. (2012). Freedom to conclude unnamed contracts and its limits. SAC Bulletin, 4, $12-56$.

Kharel, A. (2018). Doctrinal Legal Research. SSRN Electronic Journal. https://doi.org/10.2139/ssrn.3130525

Kindratenko, Z. (2018). Problems of judicial practice related to the consideration of disputes arising under rental contracts for construction in progress. Lawer, 3, 30-34.

Krajewski, M. (2014). Balancing Legal Certainty with Regulatory Flexibility (March 1, 2013) // WTO Domestic Regulation and Services Trade - Putting Principles into Practice. Cambridge.

Kratenko, M. (2007). Lease agreement for atypical facilities. Household and Law, 6, 19-29.

Ksenofontova, Yu. (2018). Interests of owners in unnamed contracts. Power. Law, 1, 248-255.

Langenbucher, K. (1998). Argument by Analogy in European Law. Cambridge Law Journal, 57(3), 481-521. https://doi.org/10.1017/S0008197398003031

Lastowka, G., \& Hunter, D. (2004). The Laws of Virtual Worlds. California Law Review, 92(1), 30-50. https://doi.org/10.2307/3481444

Lipton, J. D. (2009). Bad Faith in Cyberspace: Grounding Domain Name Theory in Trademark, Property and Restitution (October 7, 2009). Harvard Journal of Law and Technology, Forthcoming; Case Legal Studies Research Paper, 09-28.

Luneva, E. (2015). The Trends in Development of Methodology of Scientific Cognition of Civil Legal Reality. Perm University Herald. Juridical Sciences, 3(29), 117-124. https://doi.org/10.17072/1995-4190-2015-3-117-124

Lyovushkin, A., \& Fedechko, F. (2014). Legal essence of an unnamed contract and its implementation within the framework of the principle of freedom of contract. Legal World, 4, 27-30.

Lyutov, N. (2019). The transformation of labor relations and new forms of employment in the digital economy. Journal of Russian Law, 7, 115-130.

Malyushin, A. (2015). Constitutional and judicial law-making in the Russian Federation as a special form of modern law-making. Russian Justice, 10, 6-8.

Melnikov, N. (2010). Transactions with construction-in-progress objects. Household and Law, 4, 58-63.

Merrill, Th. W., \& Smith, H. E. (2000). Optimal Standardization in the Law of Property: The Numerus Clausus Principle. Yale Law Journal, 110, 4. https://doi.org/10.2307/797586

Momotov, V., Ulyotov, G., \& Markova-Murashova, S. (2011). The use of the institute of analogy in the substantive and procedural law of Russia: history and modernity. Modern Law, 10, 3-12.

Mozolin, V. (2005). The development of civil law at the present stage (discussion issues). Journal of Russian Law, 7, 33-45.

Nikitin, A. (2014). About the subject of the lease. Arbitration and civil proceedings, 11, 59-63.

Pałka, P. (2016). Redefining 'Property' in the Digital Era: When Online, Do as the Romans Did. EUI Department of Law Research Paper, 2016/08. https://doi.org/10.2139/ssrn.2749701

Portuese, A., Gough, O., \& Tanega, J. A. (2013). The Principle of Legal Certainty as a Principle of Economic Efficiency. European Journal of Legal Studies, Forthcoming; U. of Westminster School of Law Research Paper, 13-13. https://doi.org/10.2139/ssrn.2332016

Romanenko, D. (2016). Analogy in the system of Russian civil law. Actual problems of Russian law, 9, 76-80.

Rozhkova, M. (2018). Domain name rights. Internet Law: A Collection of Articles. Moscow.

Savelyev, A. (2014). Legal nature of virtual objects purchased for real money in multiplayer games. Civil Law Bulletin, 1, 127-150.

Sazhenov, A. (2018). Cryptocurrencies: dematerialization of the category of things in civil law. The Law, 9, 106121.

Schauer, F., \& Spellman, B. A. (2017). Analogy, Expertise, and Experience. University of Chicago Law Review, 
84(1).

Shevtsiv, O. (2015). Some aspects of the concept of property as an object of civil rights. Leningrad Law Journal, $4,121-128$.

Sinitsyn, S. (2017). Forecast of the development of property relations: legal understanding, civil law. Laws of Russia: experience, analysis, practice, 1,84-89.

Uda, T. (2013). What is Coworking? A Theoretical Study on the Concept of Coworking. https://doi.org/10.2139/ssrn.2937194

Valyavina, Ye. (2012). On civil turnover of construction in progress. Journal of Russian Law, 1, 46-55.

Yargina, Ye. (2003). Comparative legal analysis of rental and lease agreements. Notary, 2, 8-12.

Zarubin, A. (2018). The nature of a share in common ownership. Notary, 7, 31-34.

\section{Copyrights}

Copyright for this article is retained by the author(s), with first publication rights granted to the journal.

This is an open-access article distributed under the terms and conditions of the Creative Commons Attribution license (http://creativecommons.org/licenses/by/4.0/). 